\title{
GEOCHEMICAL AND ECOTOXICOLOGICAL EVALUATION OF AN ESTUARINE SEDIMENT SECTION AT PACOTI RIVER/CE, BRAZIL
}

\author{
I. S. SOUZA ${ }^{1,2^{*}}$ and P. A. SILVA ${ }^{2}$ \\ ${ }^{1}$ Instituto Federal de Educação, Ciência e Tecnologia do Rio Grande do Norte - IFRN \\ ${ }^{2}$ Universidade Federal do Ceará - UFC \\ ivanildo.surini@ifrn.edu.br*
}

Article received in June/2016 and accepted in September/2016

DOI: $10.15628 /$ holos.2016.4741

\section{ABSTRACT}

Pacoti estuary is located on the East coast of Ceará State/Brazil and is influenced by several sources of pollution. The sediment quality in three sampling stations was evaluated through an integrated approach. The sediments obtained were analyzed geochemically with respect to texture, organic matter, phosphorus, nitrogen and concentration of metals ( $\mathrm{Fe}, \mathrm{Pb}, \mathrm{Cu}$ and $\mathrm{Zn}$ ). Additionally, the metal loading in the sediment was determined considering a toxic risk quotient (RQ) and enrichment factor (EF). The ecotoxicological approach consisted of acute and chronic toxicity tests with species of marine invertebrates. The geochemical and
\end{abstract}

ecotoxicological data were integrated using qualitative and technical criteria for multivariate analysis. The analyses showed a moderate change in the quality of the sediment Pacoti and there are influences of different contaminant sources. For this reason, one cannot disregard the input of other contaminants, not measured in this study, which probably may also have been relevant for sediment toxicity. Nonetheless, the data suggest that $\mathrm{Pb}$ and $\mathrm{Cu}$ metals as well as $\mathrm{N}$ tended to quality degradation in depositional areas and the sediment had some influence on the biological effects observed.

KEYWORDS: Geochemistry, toxicity, contamination, estuary, sediments.

\section{AVALIAÇÃO GEOQUÍMICA E ECOTOXICOLÓGICA DE UMA SEÇÃO ESTUARINA DO SEDIMENTO DO RIO PACOTI/CE, BRASIL}

\section{RESUMO}

O estuário do Rio Pacoti está localizado no litoral leste do Estado do Ceará/Brasil e é influenciada por diversas fontes de poluição. A qualidade do sedimento em três estações de amostragem foi avaliada através de uma abordagem integrada. Os sedimentos obtidos foram analisados geoquimicamente quanto à textura, teores de $\mathrm{MO}, \mathrm{N}$ e $\mathrm{P}$ totais e concentrações de metais ( $\mathrm{Fe}, \mathrm{Pb}, \mathrm{Cu}$ e $\mathrm{Zn})$. Adicionalmente, a carga de metais no sedimento foi determinada considerando-se um quociente de risco tóxico ( $Q R$ ) e um fator de enriquecimento (EF). A abordagem ecotoxicológica consistiu em testes de toxicidade aguda e crônica com espécies de invertebrados marinhos. Os dados geoquímicos e ecotoxicológicos foram integrados utilizando critérios qualitativos e técnicas de análises multivariadas. As análises indicaram alteração moderada da qualidade dos sedimentos do baixo Pacoti e que há influências de diferentes fontes contaminantes. Por essa razão, não se pode desprezar que o input de outros contaminantes, não aferidos nesse estudo, provavelmente também podem ter sido relevantes para toxicidade do sedimento. Ainda assim, os dados sugerem que os metais $\mathrm{Pb}$ e $\mathrm{Cu}$, bem como o $\mathrm{N}$ tenderam a degradação da qualidade do sedimento nas áreas deposicionais e influenciaram os efeitos biológicos observados

PALAVRAS CHAVE: Geocquímica, toxicidade, contaminação, estuário, sedimentos. 


\section{INTRODUCTION}

Besides scientific interest, the estuaries have a key historical significance for the humanity development. About $60 \%$ of large cities distributed around the world are located in its vicinity, representing in proportion to its size one of the most valuable regions of the planet (MIRANDA; CASTRO; KJERFVE, 2002).

Over the years, the typical natural cover of these regions comes gradually being replaced by the implementation of industries, the expansion of arable areas and the urban sprawl (DIEGUES, 2001; CHEN et al., 2004; MARSHALL et al., 2010). The rapid population growth and the disorderly coastal occupation, coupled with the current hyperexpansionist economic model, leads to deterioration of these areas, as a result of the waste disposal, which can contain a variety of anthropic contamination products, such as paints, pesticides, fertilizers, drugs, minerals, detergents, personal care products, oils, batteries, plastics, pathogenic microorganisms, among others (MARINS et al., 2004; MARSHALL et al., 2010; PETROVIC et al., 2003).

This issue is quite disturbing, especially in developing countries, where the population and real estate expansion of urban centers and the diversification of industrial activities, often combined with ineffectiveness and inefficiency attributed to their waste treatment systems, represent a constant challenge to the sustainable development and environmental management of coastal regions (CHOUERI et al., 2009a; TORRES et al., 2009).

In Brazil, from 25 metropolitan regions comprising the Integrated Development Region (RIDE), which together concentrated around 90 million inhabitants - approximately $44.4 \%$ of total population of the country - 14 of them are situated in estuarine regions where settled the main industrial, petrochemical, minero-metallurgical and port systems of the country (IBGE, 2014; LUIZSILVA et al., 2006). These several uses of estuaries are able to modify the distribution and variability of their physical properties, change the concentrations of natural substances, cause the contamination of waters and adjacent sediments and therefore bring harmful effects to living resources, including risks to human health (CUCCO; UMGIESSER, 2005; MIRANDA: CASTRO; KJERFVE, 2002).

Although suffering natural influences from continents, as well as anthropic activities developed on them, the estuaries are recognized as one of the most important and productive environments on the planet, giving us naturally different ecosystem products and services (SAVAGE et al., 2012). However, when reaching the estuary, a wide variety of chemical agents become subject to a combination of degrading and non-degrading processes that can affect their fate and behavior (CHAPMAN et al., 1999), accumulating them in the environment and, therefore, generating toxic effects to the organisms and leading to commitment of ecosystem benefits.

Among these agents, heavy metals deserve special attention because they are not degradable and can be easily introduced in diverse trophic niches through bioaccumulation (NICOLAU et al., 2006; TAM; WONG, 2000; YANG et al., 2014). The main destination for most contaminants introduced into the estuaries is the sediment (BARTOLI et al., 2012). In its layers, it is possible to detect the presence of contaminants that do not remain soluble after its release on 
surface waters. Thus, besides acting as a sink, the sediment may constitute a source of contaminants and nutrients to the adjacent waters (ADAMS et al., 1992; BURTON; JOHNSTON, 2010; DELVALLS et al., 2004).

For this reason, studies on the sediment quality become a very useful tool to identify and quantify pollutant loads in estuarine ecosystems, and to assess the effects that certain contaminants cause in biological systems (ARAÚJO et al., 2009; CESAR et al., 2009; DU et al., 2012; GONÇALVES et al., 2013; LANGSTON et al., 2010; STOCK et al., 2009). In Brazil, studies in this direction are concentrated in urban and industrial areas from South and Southeast regions, such as those conducted in the port area of Santos (ABESSA et al., 2005; BURUAEM et al., 2013a; PUSCEDDU et al., 2007), in estuarine system Paranaguá Sul (CHOUERI et al., 2009b), in the Paraíba do Sul river (CARVALHO et al., 2002; ZALMON et al., 2013), in Baia de Guanabara (NETO et al., 2006; FONSECA et al., 2013; MACHADO et al., 2002), in Baia de Sepetiba (RIBEIRO et al., 2013) and in Baia de Ribeira (GOMES et al., 2009) and in Baia de Guaratuba (RODRIGUES et al., 2013). In turn, the few - but no less important - studies in this segment on the northeastern region of the country (BURUAEM et al., 2013b; NILIN et al., 2013), are being still conducted in inverse proportion and speed to the society and scientific community demand.

In the Brazilian northeastern semiarid region is one of the most important estuaries in the State of Ceará, the Pacoti River estuary. Despite being a member of an environmental protection area (APA do Pacoti) and considering the extension of other relevant ecological and socioeconomic factors, the Pacoti River estuary comes, in recent years, being subjected to a variety of anthropic pressures (GORAYEB et al., 2005; SANTANA, 2014; SANTANA et al., 2015), which can generate potentially critical points of pollution. Similarly to other estuaries in the Northeast region, sediment toxicity in Pacoti is still little studied. In this sense, the aim of this study is to assess the toxic potential of the surface sediment of an estuarine section of Pacoti River by means of geochemical analyses and ecotoxicological properties, and the integration of these two approaches using multivariate statistical tools.

\section{MATERIAL AND METHODS}

\subsection{Considerations on the Pacoti River estuary}

The Pacoti River is located in the State of Ceará, northeastern Brazil, between latitude $3^{\circ} 53^{\prime} 15^{\prime \prime S}$ and $3^{\circ} 55^{\prime} 0^{\prime \prime} S^{\prime \prime}$ and longitude $38^{\circ} 22^{\prime} 30^{\prime \prime} \mathrm{W}$ and $38^{\circ} 26^{\prime} 5^{\prime \prime} \mathrm{W}$ (LACERDA et al., 2007). It rises in the Serra de Baturite and presents a course of approximately $130 \mathrm{~km}$ following SouthwestNortheast direction (Figure 1) (BARRA et al., 2014; SANTANA, 2014). The basin of this River make up about $717 \mathrm{~km}^{2}$ between the municipalities of Aquiraz, Eusébio and Fortaleza, and is marked by the presence of numerous dams that determine the water input on the estuary. Nevertheless, the flow generated by this river is the largest in the metropolitan region of Fortaleza (RMF), with an average between 1 and $19 \mathrm{~m}^{3} \cdot \mathrm{s}^{-1}$ in the periods of drought and rainfall, respectively (ZEE, 2005). Due to low altimetric data dimensions and reduced water input, the intrusion of saline water contributes enough to salinity content in the estuary. Much of the Pacoti River basin is contained in crystalline 
terrains, and when approaching the RMF, began draining sedimentary land forming barriers and dunes. In the river mouth, the particle size is showed as silt due to high sedimentation rate (VERDE, 2009). In this stretch, the vegetation is composed of mangrove, tablelands and dunes, being dune mobility impaired by several human interventions (NILIN, 2008).

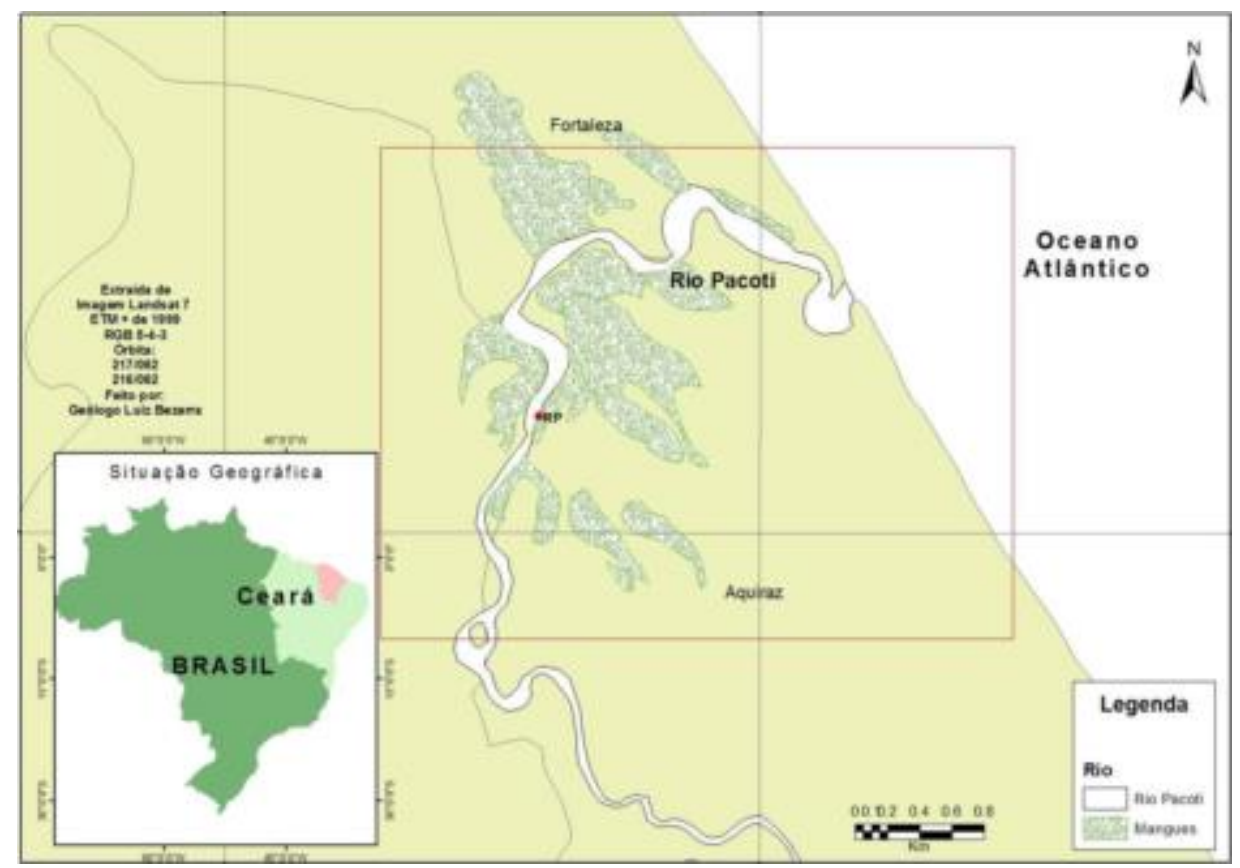

Figure 1: Location of Pacoti River/CE. Source: NILIN (2008).

The region is dry climate and sub humid, with irregular rainfall in the first half of the year, mostly between the months of February and May (rainy season), and the dry period in the second half (MORAIS et al., 2006). The low Pacoti is one of the major watercourses that cross the RMF and, although located in a conservation area, its estuary is under the real estate speculation for installation of large tourist facilities, and under influence of untreated domestic and industrial effluents, due to the accelerated growth of urban region (BARRA et al., 2014; NILIN et al., 2013; SANTANA, 2014).

Although most of the estuarine system of Pacoti River is located in the municipality of Aquiraz, the area investigated in this study is located in the municipality of Eusébio, in a section that covers the sub-basin of low Pacoti, and nearby Center for coastal aquaculture studies of the Institute of marine sciences of the Federal University of Ceará CEAC/LABOMAR/UFC.

\subsection{Collection and processing of sediment}

The collection occurred in May 2015 (rainy season), at the time of low tide of syzygy, considering three sampling stations, listed in order upstream-downstream direction, P1 to P3 (Figure 2). In each sampling station, the sediment was collected considering a line perpendicular to the River at three sites (right bank-D, left bank-E and channel-C), totaling three samples per station. 
The sediment was obtained from a superficial layer of about $5 \mathrm{~cm}$ with a plastic spatula. The sediments were then divided into two subsamples and stored in plastic bags for subsequent geochemical and ecotoxicological characterization. All samples $(n=9)$ were placed in thermal bag with ice and taken to the laboratory, where they were stored in the dark and under the temperature of $4{ }^{\circ} \mathrm{C}$ until their use. Sediment samples were also obtained from Galinhos estuary, northern coast of Rio Grande do Norte, and used as reference sediment in the analyses.

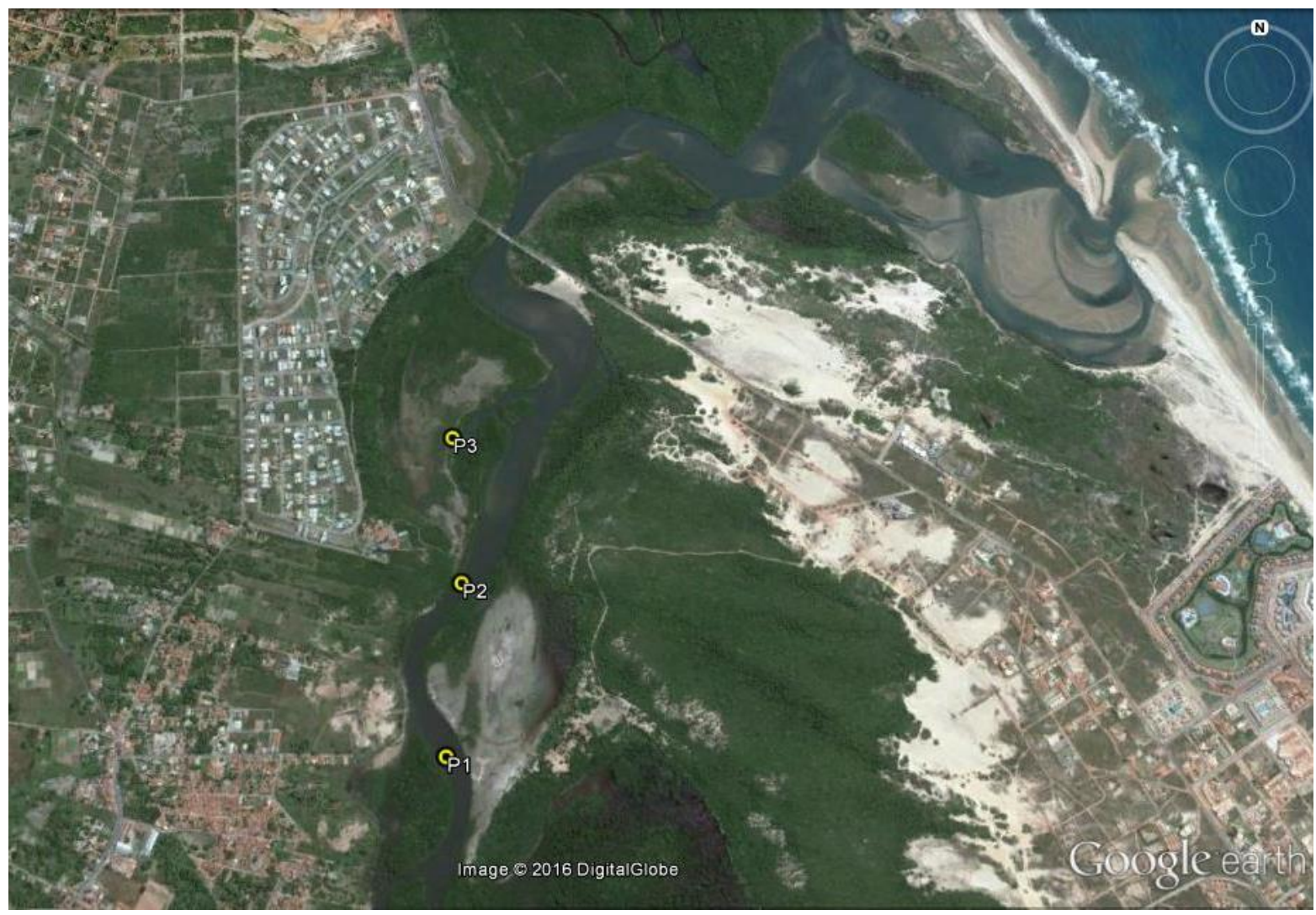

Figure 2: Location of sampling stations. (Source: Google Earth)

\subsection{Geochemical analysis}

In the laboratory, the samples for geochemical analysis were initially dried in convection oven at $45^{\circ} \mathrm{C}$ for five days, and then subdivided for particle size analysis (\% sand and fine), content of organic matter $(\mathrm{OM})$, total nitrogen $(\mathrm{N})$ and phosphorus $(\mathrm{P})$, and metallic elements $(\mathrm{Fe}, \mathrm{Cu}, \mathrm{Pb}$, $\mathrm{Zn})$.

Approximately $100 \mathrm{~g}$ of sediment were sifted, according to procedures of ABNT (1988), to separate the muddy material (silt and clay - fraction $<63 \mu \mathrm{m}$ ) from sandy (fraction $>63 \mu \mathrm{m}$ ). OM levels were analyzed by the loss on ignition method of $2 \mathrm{~g}$ dry sediment at $450{ }^{\circ} \mathrm{C}$ for $24 \mathrm{~h}$ (LORING; RANTALA, 1992), whereas the analysis of total $\mathrm{N}$ and $\mathrm{P}$ were made through the colorimetric method described by Grasshoff et al. (1999). 
Metal concentrations were obtained by digestion of $5 \mathrm{~g}$ dry sediment samples using a double-acid extraction solution of $\mathrm{HCl} 0.05 \mathrm{M}$ and $\mathrm{H}_{2} \mathrm{SO}_{4} 0,0125 \mathrm{M}$ (EMBRAPA, 1998). The digestion extracts were analyzed using atomic absorption spectrophotometer (model: Varian Spectr-AAS-220FS) calibrated via absorbance reading of six standards prepared for each metal. The analytical precision in determination of metal concentrations were established using standard reference material 1646-A from NIST (National Institute of Standards \& Technology) and were within a limit of acceptable uncertainty obtained between the values of determined and certified concentrations (recoveries between $80.7 \%$ and $114 \%$ ).

The concentrations of metals quantified in samples from Pacoti were compared to those obtained in the reference site (estuary of Galinhos, RN), and an estimated risk quotient (QR) was established through the ratio of concentrations (ROIG et al., 2015), in which it was possible to assess the sediment toxicity resulting from the contribution of the four metals analyzed, considering four risk categories : low degree $(Q R<1)$, moderate degree $(1 \leq Q R<3)$, considerable degree $(3 \leq 6<Q R)$, and very high degree (QR $\geq 6$ ) (ISLAM et al., 2015; LOSKA et al., 1997).

To differentiate the metals from anthropic activities to the natural wear, the enrichment factor (EF) was determined using the element Fe as data normalizer. Fe was selected because it has absorbing properties in tropical soils and is a conservative element of the metal phases in fluvial and coastal sediments (SCHIFF; WEISBERG, 1999). In the present study, concentrations values obtained for Nilin et al (2013) at reference sites of Pacoti estuary were considered as background. The anthropogenic impact of surface sediment was quantified by calculating the enrichment factor EF according to equation (1):

$$
\mathrm{EF}=\left([\mathrm{M}] /[\mathrm{Fe}]_{\text {sample }}\right) /\left([\mathrm{M}] /[\mathrm{Fe}]_{\text {background }}\right)
$$

Where: $[\mathrm{M}] /[\mathrm{Fe}]_{\text {sample }}$ indicates the ratio of metal concentration in analyzed sediment sample and the concentration of normalizer element Fe obtained in the same sample, and $[\mathrm{M}] /[\mathrm{Fe}]_{\text {background }}$ indicates the ratio between the metal reference value for the estuary and the normalizer Fe value on reference sediment. By means of computing a total enrichment factor ( $R$ ) obtained for each sampling point from EF values of each element, as suggested by Adamo et al., (2005), a classification of analyzed locations was performed using the criteria established by Yongming et al., (2006): extremely enriched $(R>40)$, greatly enriched $(40<R<20)$, significant enrichment $(5<R<20)$, moderately enriched $(2<R<5)$ and not enriched $(R<2)$. Thus, EF values higher than 2 may indicate anthropic sources.

\subsection{Sediment toxicity}

The integral sediment toxicity of Pacoti estuary was analyzed through acute and chronic toxicity tests, using as indication of toxic effect the mortality of amphipod Leptocheirus plumulosus and fecundity of Nitocra sp., respectively.

\subsubsection{Acute toxicity tests}

Acute toxicity tests aimed at assessing the effects caused by direct contact of organisms with sediment, i.e. through the solid phase and interstitial water together. The tests were conducted 
with amphipods of $L$. plumulosus species cultured in laboratory and followed the Protocol contained in the ABNT (2008), considering three replicas for each sediment sample. For these tests, sediment control, as well as the one used for the culture of animals, was obtained from a not impacted estuarine region in the municipality of Galinhos/RN.

The tests consisted in exposing 10 amphipods to sediment samples for a period of 10 days. In this sense, aliquots of homogenized sediment were transferred to polyethylene bottles $(1 \mathrm{~L}$ capacity), sufficient to make an uniform layer of approximately $2 \mathrm{~cm}$ thick. Then also added $700 \mathrm{~mL}$ of dilution water at $20 \%$ previously filtered on $0.45 \mu \mathrm{m}$ mesh opening. On the water surface was introduced soft aeration and the set was kept at rest by $24 \mathrm{~h}$ before the beginning of the test. After that, young animals, kept acclimated and in good condition, were randomly distributed in bottles, using three replicates per sample of sediment. During the exposure period, there was no water renewal and food was not provided. During the test, lighting conditions and continuous aeration were ensured under temperature of $25 \pm 2{ }^{\circ} \mathrm{C}$.

At the end of the exposure period, the sample contents of each replica were sifted in $0.5 \mathrm{~mm}$ mesh opening, being absent and inanimate organisms considered dead. Then, the number of dead organisms in each sample was recorded and determined the average lethality percentage. To ensure the acceptability conditions, the variables $\mathrm{pH}$, temperature, salinity and amount of dissolved oxygen in water were determined at the beginning and at the end of the test.

\subsubsection{Chronic toxicity tests}

Chronic toxicity tests with sediment aimed at assessing sublethals effects caused on benthic organisms by direct contact with the sediment samples. The test was conducted with the copepod Nitokra sp according to the method described by Lotufo and Abessa (2002) with specimens obtained from a culture kept in the laboratory.

The test was conducted in $15 \mathrm{~mL}$ scintillation vials considering three replicas for each sediment sample. Sediment control for this test was also obtained in Galinhos/RN. In each replica was introduced a layer of approximately $2 \mathrm{~g}$ of previously homogenized sediment. Subsequently, 8 $\mathrm{mL}$ of filtered seawater was added and reconstituted with $20 \%$ salinity. The content remained at rest for $24 \mathrm{~h}$. After this period, each vial received 10 ovate and healthy females. The system was maintained for seven days at a temperature of $25 \pm 2{ }^{\circ} \mathrm{C}$, without aeration and with continuous lighting. At the beginning of the test, $100 \mu \mathrm{L}$ of food consisting of a solution of yeast and water was provided. After the exposure period, the organisms were fixed with $0.5 \mathrm{~mL}$ of $4 \%$ formaldehyde, stained with $1 \mathrm{~mL}$ of $0.1 \%$ rose bengal counted in stereoscopic microscope to determine the average number of offspring (nauplius+copepodites) by female. For the test validation, the physical and chemical variables: dissolved oxygen, $\mathrm{pH}$, temperature and salinity were measured at the beginning and at the end of the experiment.

\subsection{Analysis and interpretation of data}

The toxicity data (mortality of amphipods and fecundity of copepods) were compared using one-way ANOVA and subsequently employed the T-Student test, comparing the data obtained in 
each sample with their respective controls. Significantly different samples of control were considered toxic $(p<0.05)$. Prior to application, the data were submitted to evaluation of the distribution type (normality) by chi-squared test and homogeneity of variances by Fisher's exact test.

For better interpretation results, the geochemical and toxicity data were integrated using multivariate statistical methods of hierarchical cluster analysis (HCA) and factor analysis with extraction of principal components (PCA). In this regard, data were arranged in a multivariate array containing the following geochemical variables - $\mathrm{OM}$, thin, $\mathrm{N}, \mathrm{P}, \mathrm{Fe}, \mathrm{Cu}, \mathrm{Pb}, \mathrm{Zn}$ - and ecotoxicological properties - mortality of amphipods and fecundity of copepods.

In $A C$, the similarities between sampling stations and between variables according to their sedimentary and ecotoxicological similarities were evaluated, using the Euclidean distance as measurement distance and Ward's method as grouping strategy. In AC, to establish the variables with higher significance, a cut-off factor equal to 0.40 was considered, which is in accordance with the percentage of overlapping variance established by Comrey and Lee (1992). The analysis was performed considering the axis rotation by approximated Varimax normalized rotation. To reduce size differences between variables and treats them with equal importance, the data was standardized and treated in Statistica 7 software (StatSoft Inc, Tulsa, OK, USA).

\section{RESULTS AND DISCUSSION}

\subsection{Particle size analysis}

The results of geochemical characterization of surface sediments from Pacoti estuary are summarized in Table 1. Generally, the examined particle size revealed a low textural heterogeneity in the sediment composition between the different sampling stations with sandy fraction reaching levels exceeding $80 \%$ in almost every collection sites (Figure 3). These findings are in agreement with the data of ZEE (2005), who identifies the sediment samples from low Pacoti as very sandy and points the influence of wind farm sediments, due to the lack of large bays, as the main responsible for variations in sediment deposition in estuary and mangrove areas in most estuaries in the State of Ceará.

As regards the fine fraction (silt+clay), it was observed that mud content in the estuary showed low variability and all sampled locations presented contents lower than $22 \%$, being the sites P1C, P1E, P2C and P2E with content below $10 \%$.

In general, it can be said that the textural distribution of particles demonstrates that the sediment present in the low Pacoti showed two classes with distinct depositional features. Thus, it has thicker sediments that were prevalent and found particularly on stations located on the main channel of estuary; and thinner sediments, mostly found in P3 station (located inside a stream), where sedimentation may be influenced by the movement pattern established in those parts of the estuary. 
Table 1: Results of geochemical variables (percentage of organic matter, sand, fine, and concentrations of nitrogen, phosphorus and metals - $\mathrm{Cu}, \mathrm{Pb}, \mathrm{Zn}$ and $\mathrm{Fe}$ ) obtained for sediment of three sampling stations from Pacoti estuary.



Figure 3: Particle size analysis with values of sandy and fine fraction (silt + clay), expressed in $\%$ of the studied sediments in the Pacoti estuary.

\subsection{Content of organic matter, total nitrogen and total phosphorus}

The percentages of $\mathrm{OM}$ and contents of total $\mathrm{N}$ and $\mathrm{P}$ nutrients found in sediments from Pacoti estuary are represented in Table 1 . The OM content presented a variation range between $0.78 \%$ and $3.25 \%$ in $\mathrm{P} 1$ station, between $1.78 \%$ and $2.78 \%$ in $\mathrm{P} 2$ station, and between 2.98 and $4.72 \%$ in P3, reaching in this last station relatively high values in the three collecting sites (P3D, P3C, P3E). These results comply with the OM content found in the rivers Pacoti and Ceará by Maia (2004), Aguiar (2005) and Nilin et al. (2013), which obtained contents varying between 0.64 and $9.7 \%$.

The OM distribution showed a similar pattern to that found for the fine sediments, being mud stations also rich in $\mathrm{OM}$, which may be related to increased deposition of these materials at P3 
station. The high percentage of fine sediments and organic materials in P3 station can be indicative of the presence of a relatively dense mangrove area, which tends to decrease the local hydrodynamic energy and, therefore, retain these materials in sediments. Several authors have demonstrated that inherent ability to mangroves (SILVA et al., 2007; TAM; WONG, 1996). In addition, the P3 station is under less influence of currents, making that thinner sediments and rich in $\mathrm{OM}$ deposit more intensely at the estuary bottom.

In relation to total $\mathrm{P}$, contents fluctuated between 31 and $127 \mathrm{mg} \cdot \mathrm{Kg}^{-1}$, and followed a pattern of decreasing concentration towards the mouth. For the total $\mathrm{N}$, a clear distribution pattern of their concentrations was not observed along the studied estuarine range. This nutrient content remained between 124 and $330 \mathrm{mg} / \mathrm{Kg}^{-1}$.

The high levels of $\mathrm{P}$ observed in $\mathrm{P} 1 \mathrm{C}$ and $\mathrm{P} 2 \mathrm{D}$ can be resulting from the dragging of pollutants from the surrounding urban centers, which are brought to the Pacoti estuary by the more intense surface run off from the drainage basin during the rainy season. Despite their roles as key nutrients on formation of living organisms and in biogeochemical cycle, $\mathrm{N}$ and $\mathrm{P}$ may be over introduced in coastal environments from sewers and urban effluents (MACKENZIE; CHOU, 1993), leading to critical points of eutrophication.

\subsection{Quantification of metals}

The results for content analysis of metals in sediment samples on several collection sites from Pacoti estuary are presented in Table 1. In general, most of the metallic elements presented with the highest contents at P3 station.

Fe concentrations varied between sampling stations with contents ranging from 0.39 to $0.66 \%$, in P2C (P2 station) and P3E (P3 station), respectively. The highest Cu concentrations, in turn, were observed in collection sites belonging to $\mathrm{P} 3$ station, where ranged from 0.92 to $2.23 \mathrm{mg}$. $\mathrm{Kg}^{-1}$. Similarly as $\mathrm{Cu}$, the $\mathrm{Pb}$ and $\mathrm{Zn}$ also obtained their highest concentrations at $\mathrm{P} 3$ station. $\mathrm{Pb}$ levels ranged from $1.06 \mathrm{mg} \cdot \mathrm{Kg}^{-1}$ at $\mathrm{P} 2 \mathrm{E}$ site to $3.79 \mathrm{mg} \cdot \mathrm{Kg}^{-1}$ at $\mathrm{P} 2 \mathrm{C}$. Whereas the levels of $\mathrm{Zn}$ ranged between 1.61 and $4.92 \mathrm{mg} . \mathrm{Kg}^{-1}$, at P2C and P3D sites, respectively.

The contents obtained for the metals in the present study were lower than those from global geological reference levels, compiled by Turekian and Wedepohl (1961) and the reference sediment adopted by the Brazilian legislation (CONAMA, 2012). But even with a weak acid extraction, such contents were within similar ranges of past studies conducted at Pacoti and other estuaries in Brazil and around the world (SINDERN et al., 2007; RODRIGUES et al., 2013; PAULA FILHO et al., 2015; VAN DEN HURK et al., 1997; CASADO-MARTÍNEZ et al., 2009). The inadequacy of using international reference values for comparative purposes in sediment quality studies has already been widely discussed by Marins et al., (2004), and they demonstrated that the same should be avoided, prioritizing, on the other hand, local or regional background values. For this reason, it is believed that the risk quotient (RQ) adopted in this study reports with higher predictive power the current geochemical conditions of Pacoti estuary. 


\subsection{Metal enrichment factor (EF) and toxic risk quotient (RQ)}

The values for geochemical indices $R Q$ and EF obtained in sediments from Pacoti are presented in Tables 2 and 3, respectively. Total EF ranged from 0 to 3.6 and identified P1 and P3 as the sampling stations with higher metal enrichment, each with two moderately enriched sites. RQ data, in turn, showed that all sampled sediments at P3 station feature moderate level of contamination $(1 \leq R Q<3)$. However, in $P 1$, two samples (P1D and P1E) showed moderate risk, while in $\mathrm{P} 2$ only $\mathrm{P} 2 \mathrm{D}$ sample showed some risk of contamination.

$\mathrm{EF}$ and RQ data obtained for sampling stations showed consistency and exhibited a similar pattern of metal accumulation in almost all collection sites. These results show a certain metal enrichment in surface layers of sediments, reflecting possible additional contributions from anthropic sources. Even though inserted in an environmental protection area since 2000 (CEARÁ, 2000), such enrichment in Pacoti estuary can be a result of impacts associated with the misuse of water resources, whether by tourist activities and/or by deforestation in the region of dunes and mangroves, which trigger erosion and siltation, and can result as more drastic result the intensified loading of metal and other pollutants to the estuarine system of Pacoti. In this same perspective, Nilin (2008) and Bezerra (2006) highlight that real estate speculation and urban density are presented as the main contributors to degradation of Pacoti River.

Table 2: Metal enrichment factor (EF) for sediment of sampling stations from Pacoti estuary.

\begin{tabular}{|c|c|c|c|c|c|c|}
\hline \multirow{2}{*}{ Stations } & \multirow{2}{*}{ Sites } & \multicolumn{3}{|c|}{ Enrichment factor (EF) } & \multirow{2}{*}{ EF-total } & \multirow{2}{*}{ Classification } \\
\hline & & $\mathrm{Cu}$ & $\mathrm{Pb}$ & $\mathrm{Zn}$ & & \\
\hline \multirow{3}{*}{ P1 } & P1D & 6,6291 & 0,0897 & 0,5313 & 2,4 & Moderate enrichement \\
\hline & P1C & $-0,6763$ & 0,1135 & 0,4151 & 0,0 & Non-enriched \\
\hline & P1E & 7,5459 & 0,3247 & 0,4112 & 2,8 & Moderate enrichement \\
\hline \multirow{3}{*}{$\mathrm{P} 2$} & P2D & 6,0584 & 0,1755 & 0,4334 & 2,2 & Moderately enriched \\
\hline & $\mathrm{P} 2 \mathrm{C}$ & 0,0519 & 0,3086 & 0,3302 & 0,2 & Non-enriched \\
\hline & $\mathrm{P} 2 \mathrm{E}$ & 0,9774 & 0,0705 & 0,5356 & 0,5 & Non-enriched \\
\hline \multirow{3}{*}{ P3 } & P3D & 2,1313 & 0,2143 & 1,1493 & 1,2 & Non-enriched \\
\hline & P3C & 8,0218 & 0,4176 & 0,4969 & 3,0 & Moderate enrichement \\
\hline & P3E & 9,8125 & 0,2217 & 0,7561 & 3,6 & Moderate enrichement \\
\hline
\end{tabular}

Table 3: Toxic risk quotient (RQ) for sediment of sampling stations from Pacoti estuary.

\begin{tabular}{|c|c|c|c|c|c|c|c|}
\hline \multirow{2}{*}{ Stations } & \multirow{2}{*}{ Sites } & \multicolumn{4}{|c|}{ Risk quotient (RQ) } & \multirow{2}{*}{ Total RQ } & \multirow{2}{*}{ Classification } \\
\hline & & $\mathrm{Fe}$ & $\mathrm{Cu}$ & $\mathrm{Pb}$ & $\mathrm{Zn}$ & & \\
\hline \multirow{3}{*}{ P1 } & P1D & 1.2 & 1.4 & 0.4 & 1.7 & 1.2 & Moderate degree \\
\hline & P1C & 1.3 & 0.4 & 0.5 & 1.5 & 0.9 & Low degree \\
\hline & P1E & 0.9 & 1.4 & 0.9 & 1.4 & 1.2 & Moderate degree \\
\hline \multirow{3}{*}{$\mathrm{P} 2$} & P2D & 1.3 & 1.3 & 0.6 & 1.5 & 1.2 & Moderate degree \\
\hline & $\mathrm{P} 2 \mathrm{C}$ & 0.8 & 0.3 & 0.9 & 1.1 & 0.8 & Low degree \\
\hline & $\mathrm{P} 2 \mathrm{E}$ & 1.1 & 0.6 & 0.3 & 1.7 & 0.9 & Low degree \\
\hline \multirow{3}{*}{ P3 } & P3D & 1.2 & 0.8 & 0.7 & 3.3 & 1.5 & Moderate degree \\
\hline & P3C & 0.9 & 1.5 & 1.2 & 0.9 & 1.3 & Moderate degree \\
\hline & P3E & 1.4 & 1.9 & 0.8 & 2.4 & 1.6 & Moderate degree \\
\hline
\end{tabular}




\subsection{Sediment toxicity}

Sediment toxicity tests are technically well developed, widely used, and accepted as environmental tools useful for a wide variety of research purposes and regulations (USEPA, 1994; BURTON, 1991). However, predicting the bioavailability and toxicity of contaminants in aquatic sediments is a critical component in the development of sediment quality criteria (CESAR et al., 2009). To minimize this issue and ensure a better observation of bioavailability and toxicity of metals, the present study considered an ecotoxicological approach that combines the acute and chronic biological responses in a decision table (Table 4) to identify and classify with greater predictive power the toxic potential of the sediment. For such purpose, after they have been assessed in relation to toxicity ( $p \leq 0.05)$, sediments were classified qualitatively by adopting the following criterion: non-degraded, when there is lack of toxicity in two tests; moderately degraded, toxicity identified in only one test; and degraded, when toxicity is present in both tests.

Table 4: Results (average \pm standard deviation) of acute and chronic toxicity tests, and ecotoxicological classification of sediment samples from Pacoti estuary and experimental control (Galinhos estuary).

\begin{tabular}{|c|c|c|c|c|}
\hline \multirow[b]{2}{*}{ Stations } & \multirow[b]{2}{*}{ Site } & Acute toxicity & Chronic toxicity & \multirow[b]{2}{*}{ Ecotoxicological classification } \\
\hline & & $\begin{array}{l}\text { L. plumulosus } \\
\text { (\%Mortality) }\end{array}$ & $\begin{array}{c}\text { Nitokra sp. } \\
\text { (\%Nauplius + copepodites) }\end{array}$ & \\
\hline \multirow{3}{*}{ P1 } & P1D & $0 \pm 0$ & $45.3 \pm 1.0$ & Non-degraded \\
\hline & $\mathrm{P} 1 \mathrm{C}$ & $5.0 \pm 5.0$ & $33.9 \pm 3.9$ & Non-degraded \\
\hline & P1E & $3.3 \pm 2.9$ & $29.5 \pm 7.4$ & Non-degraded \\
\hline \multirow{3}{*}{ P2 } & P2D & $13.3 \pm 7.6$ & $30.1 \pm 1.6$ & Non-degraded \\
\hline & $\mathrm{P} 2 \mathrm{C}$ & $13.3 \pm 18.9$ & $34.7 \pm 8.9$ & Non-degraded \\
\hline & $\mathrm{P} 2 \mathrm{E}$ & $1.7 \pm 2.9$ & $14.4 \pm 7.5^{* *}$ & Moderately degraded \\
\hline \multirow{3}{*}{ P3 } & P3D & $11.7 \pm 12.6$ & $29.7 \pm 1.8$ & Non-degraded \\
\hline & P3C & $30.0 \pm 5.0 * *$ & $27.3 \pm 5.9 * *$ & Degraded \\
\hline & P3E & $1.7 \pm 2.9$ & $16.1 \pm 7.4^{* *}$ & Moderately degraded \\
\hline Control & Galinhos/RN & $3.3 \pm 5.8$ & $41.6 \pm 3.3$ & - \\
\hline
\end{tabular}

** Significant difference compared to the control group $(p<0.05)$.

As can be verified in Table 4, only the sediment from P3C site resulted concurrently in acute and chronic responses, being observed mortality equal to $30 \pm 5 \%$ and fecundity rate equal to $27.3 \pm 5.9 \%$, which characterizes this sample, according to the ecotoxicological approach, as

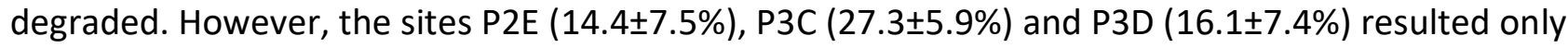
in chronic effects. On the other hand, there was not any station showing exclusively acute toxicity.

Not surprisingly, the chronic toxicity test was more sensitive than the acute toxicity test. This fact highlights the need to assign, on the ecotoxicological tests, higher weight to acute effects in decision-making to promote a more cautious classification of sediments and thus be able to detect preventively (precautionary principle) possible severe changes on their quality. Acute and chronic effects at Pacoti estuary were also found by Nilin (2008; 2013), which observed for the amphipod 
Tiburonella viscana survival values less than $55 \%$ and for sea urchin embryos from Lytechinus variegatus species a high percentage of abnormality (32.2\%) in embryo-larval development.

\subsection{Hierarchical cluster analysis (HCA)}

The results of HCA performed to collection stations have resulted in the formation of three larger clusters (Figure 4a). The first cluster grouped P1D, P2D, P1C and P2E, and showed intermediate levels of basically all geochemical variables analyzed. The second cluster grouped the sites P1E, P2C and P3C, with low levels of fines, P and Zn; intermediate levels of OM; and relatively high levels of $\mathrm{N}$ and $\mathrm{Pb}$. The toxicity data included in this cluster still indicated that only the sediments from P3C site showed severe toxicity, i.e. acute and chronic, concurrently. P3D and P3E sites, in turn, were grouped in the fourth cluster, with high levels of $\mathrm{OM}$, fines, $\mathrm{N}$ and metals, besides low P content. Toxicity datas the sediment sampled at P3E site as the only one with a certain toxic potential (chronic).

Thus, the cluster results for the sampling stations allows us to infer that the sediments from $\mathrm{P} 1$ and $\mathrm{P} 2$ have geochemical and toxicological characteristics more similar and less toxic potential than P3 station, which identified sediments collected at P3C site as with higher toxicity.

The grouping analysis obtained for geochemical and ecotoxicological variables identified four clusters (Figure 4b). The first represented $\mathrm{P}$ nutrient and Fe metal; the second grouped $\mathrm{Zn}$ with sediment properties (OM content and fines); the third cluster, in turn, was formed by N, Cu and chronic toxicity (fecundity of copepods), while the fourth cluster grouped the mortality of amphipods (acute toxicity) and $\mathrm{Pb}$ metal. These data suggest that the existing sources of nutrients and metals in this stretch of Pacoti estuary can be from different origins.

(a) Grouping the samplig stations

Ward's method

Euclidean distances

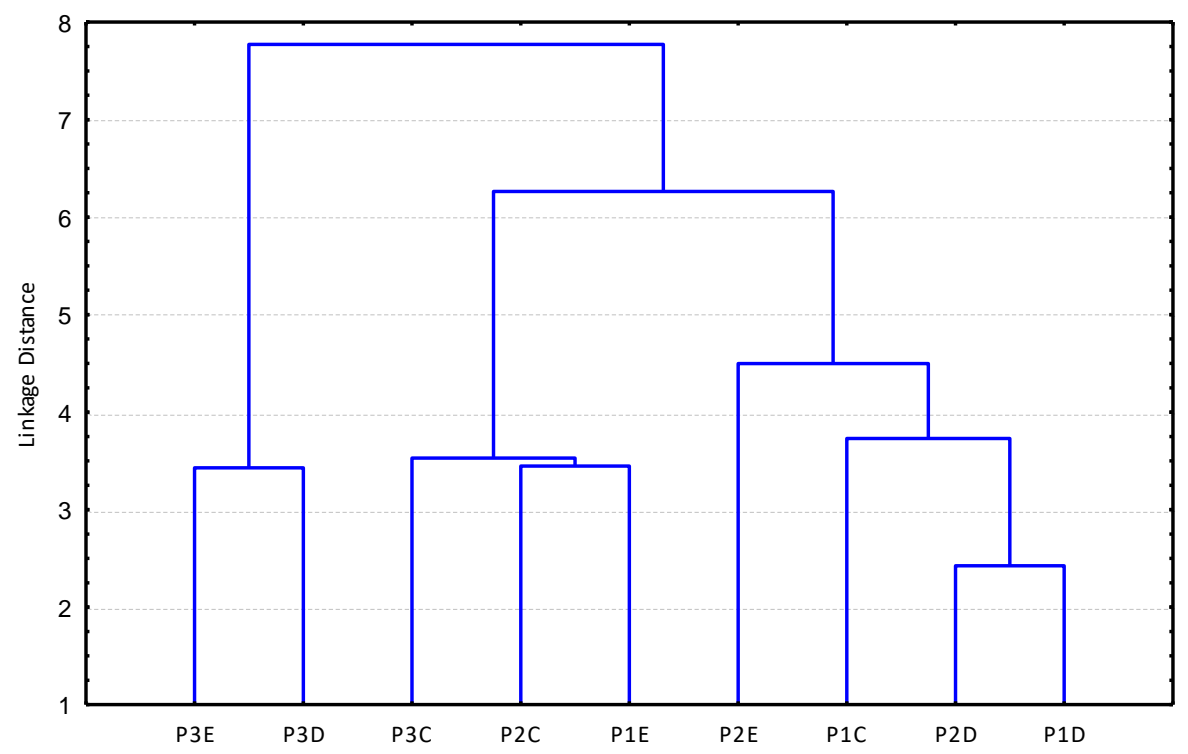


(b) Grouping the geochemical and ecotoxicological variables

Ward's method

Euclidean distances

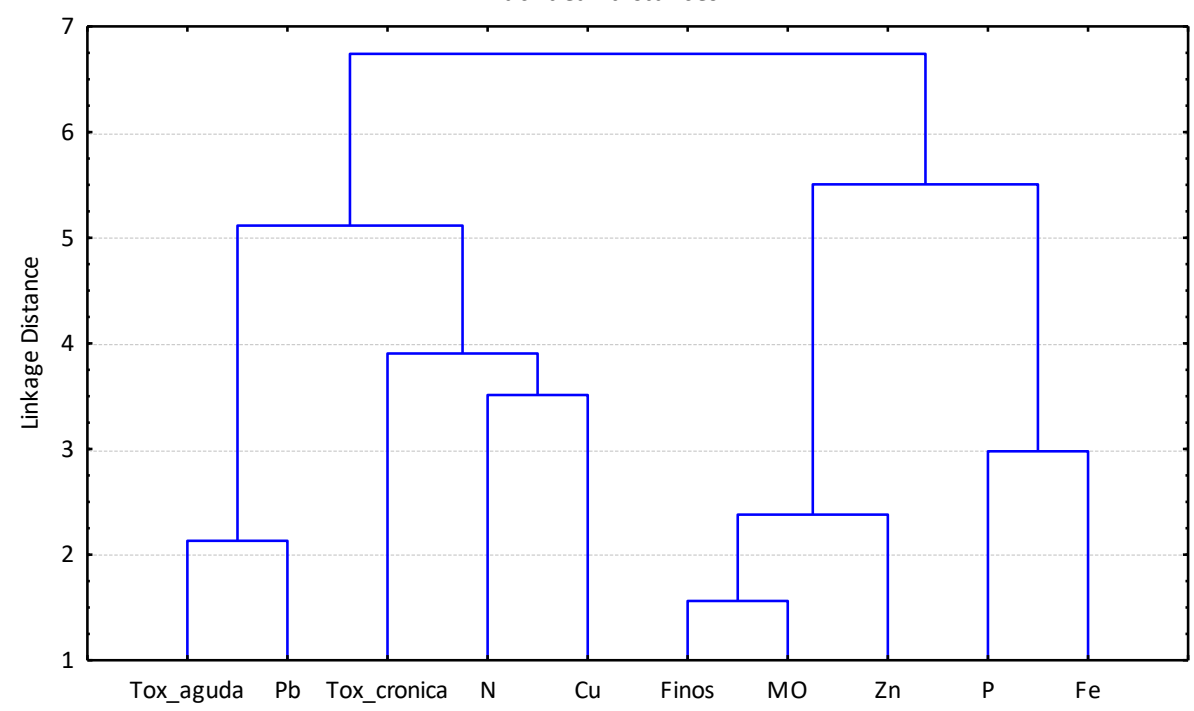

Figure 4: Hierarchical clustering for sediment data from Pacoti estuary, grouping the sampling stations (a) and geochemical and ecotoxicological variables (b).

\subsection{Principal component analysis (PCA)}

The factor analysis reorganized the original data and created four key factors that, together, explained $87.51 \%$ of total variance of the original data. As can be seen in Table 5, each axis explained a relatively small percentage of variances, which is expected in heterogeneous environments, where the interactions between variables are intense and complex (RODRIGUES et al., 2013).

Table 5: Eigenvalues and eigenvectors obtained by PCA using geochemical and ecotoxicological data of sediments from Pacoti estuary (cut-off value $>0.40$ ). Bold values indicate stronger correlations.

\begin{tabular}{lcccc}
\hline Variables & Factor 1 & Factor 2 & Factor 3 & Factor 4 \\
\hline $\mathrm{Fe}$ & $\mathbf{0 . 6 5}$ & $\mathbf{0 . 6 0}$ & -0.02 & $\mathbf{0 . 4 1}$ \\
$\mathrm{Cu}$ & $\mathbf{0 . 5 1}$ & $-\mathbf{0 . 4 2}$ & 0.31 & $\mathbf{0 . 6 6}$ \\
$\mathrm{Pb}$ & 0.01 & $-\mathbf{0 . 9 2}$ & -0.23 & -0.02 \\
$\mathrm{Zn}$ & $\mathbf{0 . 8 4}$ & 0.10 & -0.07 & -0.25 \\
$\mathrm{~N}$ & $\mathbf{0 . 5 9}$ & -0.35 & $\mathbf{0 . 4 6}$ & $\mathbf{0 . 4 5}$ \\
$\mathrm{P}$ & -0.25 & $\mathbf{0 . 6 6}$ & $-\mathbf{0 . 5 0}$ & $\mathbf{0 . 4 3}$ \\
$\mathrm{OM}$ & $\mathbf{0 . 8 7}$ & -0.37 & 0.01 & 0.12 \\
Fines & $\mathbf{0 . 9 6}$ & -0.07 & -0.22 & -0.05 \\
Acute toxicity & -0.12 & $-\mathbf{0 . 6 8}$ & $-\mathbf{0 . 5 4}$ & 0.05 \\
Chronic toxicity & 0.28 & 0.06 & $\mathbf{0 . 7 4}$ & -0.26 \\
\hline Eigenvalues & 3.53 & 2.55 & 1.50 & 1.13 \\
\%Total Variance & 35.53 & 25.59 & 15.05 & 11.34 \\
\%Cumulative variance & 35.53 & 61.13 & 76.17 & 87.51 \\
\hline
\end{tabular}


The predominant factor (F1) explained $35.53 \%$ of total variance and related positively the metals $\mathrm{Fe}, \mathrm{Cu}, \mathrm{Zn}$ with OM content and fine content. The sites P3D and P3E were those who most contributed to the formation of this component (Figure 5). A negative correlation was observed for all these variables with $\mathrm{N}$, which indicates that its origin/source may be different from metals. The strong association observed between the Fe conservative metal and features, $\mathrm{Cu}$ and $\mathrm{Zn}$, in turn, deduces that these elements are from lithogenic sources, since Fe generally has its natural concentrations relatively high and therefore should not be substantially enriched from anthropic sources in estuarine sediments (NIENCHESKI et al., 1994). Furthermore, the high correlation of these metals with $\mathrm{OM}$ and fines also suggests that these are important geochemical carrier of metals, forming complexes and depositing in the sediment of closed areas of estuary (streams and gamboas) and with less hydrodynamic power, featuring a local enrichment.

Aguiar (2005), when assessing contamination levels by the metals $\mathrm{Cu}$ and $\mathrm{Zn}$ through geochemical distribution and partition of metals in estuaries of Ceará, observed a differentiated behavior in the estuaries of the rivers Ceará and Pacoti, the first obtaining higher contents of metals mainly related to diffuse sources of contamination. At Pacoti River, the increment of metals was related to lithogenic sources.

The extraction of the second factor (F2) explained $25.59 \%$ of variance and positively associated Fe and P. In contrast, a negative correlation was observed between these elements and the mortality of $L$. plumulosus and the metals $\mathrm{Cu}$ and $\mathrm{Pb}$. In this case, $\mathrm{P} 3 \mathrm{C}$ site was what influenced the formation of $\mathrm{F} 2$ factor (Figure 5). These findings corroborate the data obtained by $\mathrm{AC}$ and may indicate that the toxicity on P3C is directly influenced by deposition of the elements $\mathrm{Cu}$ and $\mathrm{Pb}$.

In waters and sediments, $\mathrm{Pb}$ and $\mathrm{Cu}$ can be deposited from the atmosphere or the soil leaching, from natural sources (erosion of contaminated soil) or from anthropic sources. One of the major anthropic sources of emission of these elements in the environmental are the operations of production and processing of metal, iron and steel industry and metal refining, urban runoff (household waste), manufacture processes of chemicals and paper, and agricultural inputs (AZEVEDO; CHASIN, 2003). Regarding the Pacoti, Santana (2014) found that the estuary is under ecological risk between moderate and severe, and pointed as possible anthropic sources of metallic elements the residential allotment, industries, subsidence agriculture, the tourism, the presence of boats, and shrimp farming. 

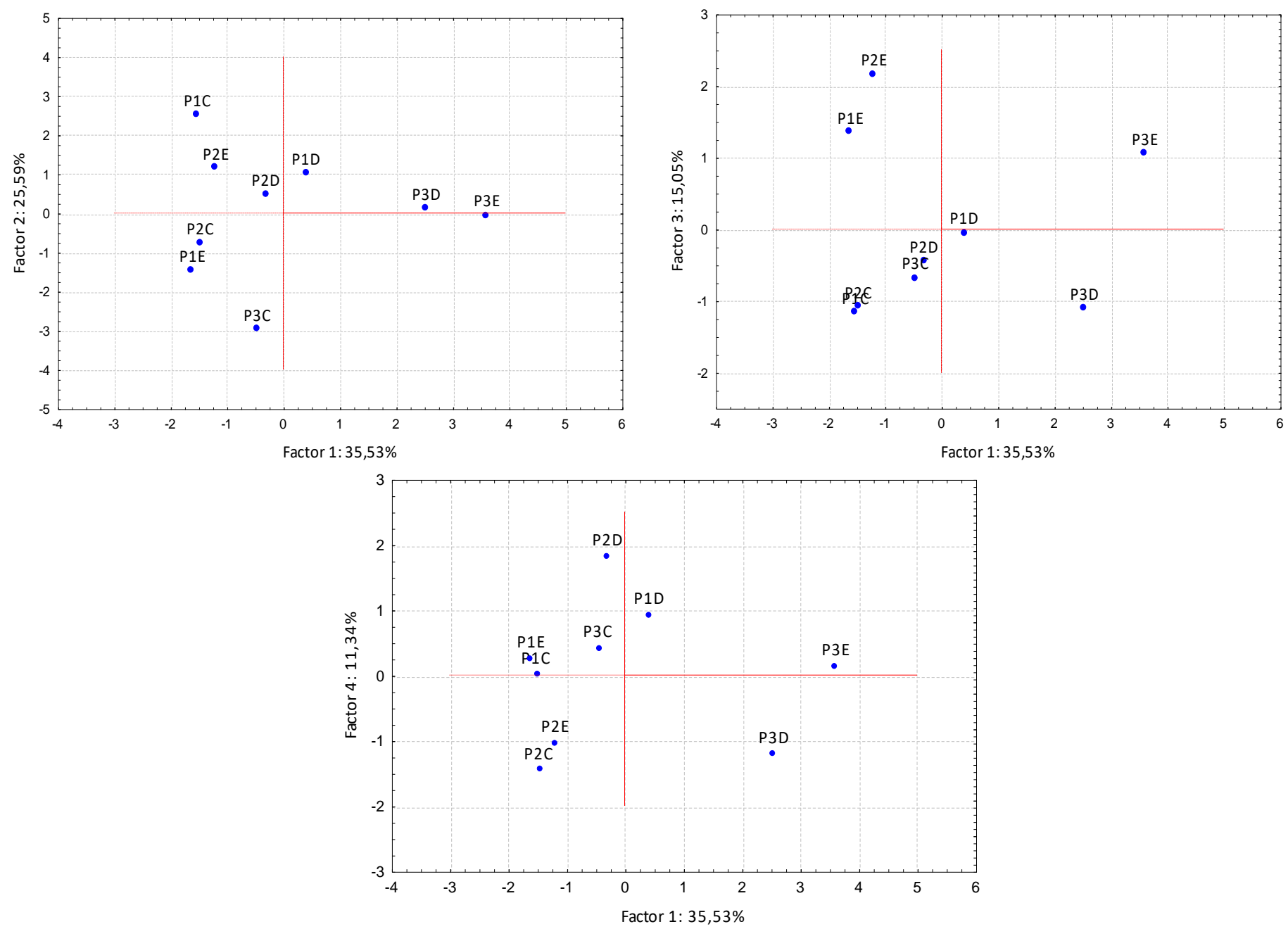

Figure 5: Score of the four principal components (Factor 1, Factor 2, Factor 3 and factor 4) from geochemical and ecotoxicological data of sampled sediment at Pacoti estuary.

The F3 factor explained $15.5 \%$ of data and associated N positively with chronic toxicity and $P$ with acute toxicity, suggesting that there are sources of these elements triggering toxic effects in the estuary and that these may be different. P2E site was what more contributed to the formation of this component. These findings are consistent with data from AC, which indicate high concentrations of $\mathrm{N}$ and prejudice to fecundity of copepods. In turn, the factor 4 explained only $11.34 \%$ of data and positively correlated $\mathrm{Fe}, \mathrm{Cu}, \mathrm{N}$ and $\mathrm{P}$, signaling this component as a possible determinant of natural origin (lithogenic) of these elements. As can be observed in Figure 5, P2D site was what more contributed to the formation of this component.

\section{CONCLUSION}

The analyses demonstrated that there are pollution signs at Pacoti estuary arising from the influence of different contaminants that have created a heterogeneous scenario from the geochemical and ecotoxicological point of view. Thereby, one cannot disregard the input of other 
contaminants, not measured in this study, which probably may also have been relevant for sediment toxicity. Nonetheless, the analyses suggested that $\mathrm{Pb}$ and $\mathrm{Cu}$ metals, as well as total $\mathrm{N}$, and total $\mathrm{P}$ in lesser intensity, tended to quality degradation in depositional areas and the sediment had some influence on the biological effects observed. In short, the data indicated moderate change of sediment quality at low Pacoti, being recommended complementary studies with sampling expansion and inclusion of different contaminant groups to broaden the knowledge of toxic standard here found.

\section{REFERENCES}

1. Abessa, D.M.S., Carr, R.S., Rachid, B.R.F., Sousa, E.C.P.M., Hortelani, M. a, Sarkis, J.E., 2005. Influence of a Brazilian sewage outfall on the toxicity and contamination of adjacent sediments. Mar. Pollut. Bull. 50, 875-85.

2. Adamo, P., Arienzo, M., Imperato, M., Naimo, D., Nardi, G., Stanzione, D., 2005. Distribution and partition of heavy metals in surface and sub-surface sediments of Naples city port. Chemosphere 61, 800-9.

3. Adams, W.; Kimerle, R.; Barnett, J., 1992. Sediment quality and Aquatic Life Assessment. Environ. Sci. Technol. 26, 1864-1875.

4. Araújo, C.V.M., Diz, F.R., Laiz, I., Lubián, L.M., Blasco, J., Moreno-Garrido, I., 2009. Sediment integrative assessment of the Bay of Cádiz (Spain): An ecotoxicological and chemical approach. Environ. Int. 35, 831-841.

5. Bartoli, G., Papa, S., Sagnella, E., Fioretto, A., 2012. Heavy metal content in sediments along the Calore river : Relationships with physical e chemical characteristics. J. Environ. Manage. 95, S9S14.

6. Burton, G.A., Johnston, E.L., 2010. Assessing contaminated sediments in the context of multiple stressors. Environ. Toxicol. Chem. 29, 2625-2643.

7. Buruaem, L.M., Araujo, G.S., Rosa, P.A., Nicodemo, S.C., Porto, V.F., Fonseca, J.R., Cruz, J. V., Medeiros, G.F., Abessa, D.M.S., 2013. Assessment of sediment toxicity from the Areia Branca off-shore harbor and the Potengi river estuary (RN), northeastern Brazil. Panam. J. Aquat. Sci. 8, 312-326.

8. Buruaem, L.M., de Castro, Í.B., Hortellani, M.A., Taniguchi, S., Fillmann, G., Sasaki, S.T., Varella Petti, Mô.A., Sarkis, J.E.D.S., Bícego, M.C., Maranho, L.A., Davanso, M.B., Nonato, E.F., Cesar, A., Costa-Lotufo, L.V., Abessa, D.M.D.S., 2013. Integrated quality assessment of sediments from harbour areas in Santos-São Vicente Estuarine System, Southern Brazil. Estuar. Coast. Shelf Sci. 130, 179-189.

9. Carvalho, C.E. V, Salomão, M.S.M.B., Molisani, M.M., Rezende, C.E., Lacerda, L.D., 2002. Contribution of a medium-sized tropical river to the particulate heavy-metal load for the South Atlantic Ocean. Sci. Total Environ. 284, 85-93.

10. Cesar, A., Marín, A., Marin-Guirao, L., Vita, R., Lloret, J., Del Valls, T.A., 2009. Integrative ecotoxicological assessment of sediment in Portmán Bay (southeast Spain). Ecotoxicol. Environ. Saf. 72, 1832-1841. 
11. Chapman, P.M., Wang, F., Adams, W.J., Utah, K., Corporation, C., Box, P.O., Green, A., 1999. Appropriate Applications of Sediment Quality Values for Metals and Metalloids. Environ. Sci. Technol. 33, 3937-3941.

12. Chen, Z., Saito, Y., Kanai, Y., Wei, T., Li, L., Yao, H., Wang, Z., 2004. Low concentration of heavy metals in the Yangtze estuarine sediments, China: A diluting setting. Estuar. Coast. Shelf Sci. 60, 91-100.

13. Choueri, R.B., Cesar, a, Torres, R.J., Abessa, D.M.S., Morais, R.D., Pereira, C.D.S., Nascimento, M.R.L., Mozeto, a a, Riba, I., DelValls, T. a, 2009. Integrated sediment quality assessment in Paranaguá Estuarine System, Southern Brazil. Ecotoxicol. Environ. Saf. 72, 1824-31.

14. DelValls, T. a., Andres, a., Belzunce, M.J., Buceta, J.L., Casado-Martinez, M.C., Castro, R., Riba, I., Viguri, J.R., Blasco, J., 2004. Chemical and ecotoxicological guidelines for managing disposal of dredged material. TrAC - Trends Anal. Chem. 23, 819-828.

15. Du, J., Mehler, W.T., Lydy, M.J., You, J., 2012. Toxicity of sediment-associated unresolved complex mixture and its impact on bioavailability of polycyclic aromatic hydrocarbons. J. Hazard. Mater. 203-204, 169-75.

16. EMBRAPA - Empresa Brasileira de Pesquisa Agropecuária, 1998. Análises químicas para avaliação da fertilidade do solo. Métodos usados na Embrapa Solos 40.

17. Fonseca, E.M., Neto, J.A.B., Silva, C.G., Mcalister, J.J., Smith, B.J., Fernandez, M.A., 2013. Estuarine, Coastal and Shelf Science Stormwater impact in Guanabara Bay (Rio de Janeiro ): Evidences of seasonal variability in the dynamic of the sediment heavy metals. Estuar. Coast. Shelf Sci. 130, 161-168.

18. Gonçalves, S.F., Calado, R., Gomes, N.C.M., Soares, A.M.V.M., Loureiro, S., 2013. An ecotoxicological analysis of the sediment quality in a European Atlantic harbor emphasizes the current limitations of the Water Framework Directive. Mar. Pollut. Bull. 72, 197-204.

19. Islam, S., Ahmed, K., Raknuzzaman, M., 2015. Heavy metal pollution in surface water and sediment : A preliminary assessment of an urban river in a developing country. Ecol. Indic. 48, 282-291.

20. Langston, W.J., Pope, N.D., Jonas, P.J.C., Nikitic, C., Field, M.D.R., Dowell, B., Shillabeer, N., Swarbrick, R.H., Brown, a R., 2010. Contaminants in fine sediments and their consequences for biota of the Severn Estuary. Mar. Pollut. Bull. 61, 68-82.

21. Loska, K., Cebula, J., Pelczar, J., Wiechuła, D., Kwapuliński, J., 1997. Use of enrichment, and contamination factors together with geoaccumulation indexes to evaluate the content of $\mathrm{Cd}$, $\mathrm{Cu}$, and $\mathrm{Ni}$ in the Rybnik water Reservoir in Poland. Water. Air. Soil Pollut. 93, 347-365.

22. Luiz-silva, W., Helena, R., Matos, R., Kristosch, C., Machado, W., 2006. Variabilidade espacial e sazonal da concentração de elementos-traço em sedimentos do sistema estuarino de SantosCubatão (SP). Quim. Nova 29, 256-263.

23. Machado, W., Moscatelli, M., Rezende, L.G., Lacerda, L.D., 2002. Mercury, zinc, and copper accumulation in mangrove sediments surrounding a large landfill in southeast Brazil. Environ. Pollut. 120, 455-61.

24. Maia, S.R.R. Distribuição e partição geoquímica de metais traço na costa norte de Fortaleza, CE. 
Dissertação de mestrado. Instituto de Ciências do Mar. Universidade Federal do Ceará. 105p. 2004

25. Marins, R. V, José, F., Filho, D.P., Rodrigues, R., Lacerda, L.D. De, 2004. Total mercury distribution as a proxy of urban and industrial pollution along the brazilian. Quim. Nova 27, 763770.

26. Marshall, S., Pettigrove, V., Carew, M., Hoffmann, A., 2010. Isolating the impact of sediment toxicity in urban streams. Environ. Pollut. 158, 1716-25.

27. Neto, J.A.B., Gingele, F.X., Leipe, T., Brehme, I., 2006. Spatial distribution of heavy metals in surficial sediments from Guanabara Bay: Rio de Janeiro, Brazil. Environ. Geol. 49, 1051-1063.

28. Nicolau, R., Galera-Cunha, a., Lucas, Y., 2006. Transfer of nutrients and labile metals from the continent to the sea by a small Mediterranean river. Chemosphere 63, 469-476.

29. Niencheski, L.F., Windom, H.L., Smith, R., 1994. Distribution of particulate trace metal in the southern part of the Patos Lagoon estuary. Aquat. Ecosyst. Health Manag. 28, 96-102.

30. Nilin, , J. Avaliação da qualidade do sedimento do Ceará. Dissertação de Mestrado em Ciências Marinhas tropicais - Universidade Federal do Ceará, Fortaleza. 93p. 2008.

31. Nilin, J., Moreira, L.B., Aguiar, J.E., Marins, R., de Souza Abessa, D.M., da Cruz Lotufo, T.M., Costa-Lotufo, L.V., 2013. Sediment quality assessment in a tropical estuary: the case of Ceará River, Northeastern Brazil. Mar. Environ. Res. 91, 89-96.

32. Petrovic, M., Gonzalez, S., Barceló, D., 2003. Analysis and removal of emerging contaminants in wastewater and drinking water. Trends Anal. Chem. 22, 685-696.

33. Pusceddu, F.H., Alegre, G.F., Pereira, C.D.S., Cesar, a., 2007. Avaliação da Toxicidade do Sedimento do Complexo Estuarino de Santos Empregando Ouriços-do-mar Lytechinus variegatus (Echinoidea: Echinodermata). J. Brazilian Soc. Ecotoxicol. 2, 237-242.

34. Ramos e Silva, C. a, Oliveira, S.R., Rêgo, R.D.P., Mozeto, A. a, 2007. Dynamics of phosphorus and nitrogen through litter fall and decomposition in a tropical mangrove forest. Mar. Environ. Res. 64, 524-34.

35. Ré, A., Freitas, R., Sampaio, L., Rodrigues, A.M., Quintino, V., 2009. Chemosphere Estuarine sediment acute toxicity testing with the European amphipod. Chemosphere 76, 1323-1333.

36. Rodrigues, S.K., Abessa, D.M.S., Machado, E.C., 2013. Geochemical and ecotoxicological assessment for estuarine surface sediments from Southern Brazil. Mar. Environ. Res. 91, 68-79.

37. Roig, N., Sierra, J., Nadal, M., Moreno-Garrido, I., Nieto, E., Hampel, M., Gallego, E.P., Schuhmacher, M., Blasco, J., 2015. Assessment of sediment ecotoxicological status as a complementary tool for the evaluation of surface water quality: the Ebro river basin case study. Sci. Total Environ. 503-504, 269-278.

38. Savage, C., Thrush, S.F., Lohrer, A.M., Hewitt, J.E., 2012. Ecosystem services transcend boundaries: Estuaries provide resource subsidies and influence functional diversity in coastal benthic communities. PLoS One 7, 1-9.

39. Tam, N.F., Wong, Y.S., 2000. Spatial variation of heavy metals in surface sediments of Hong Kong mangrove swamps. Environ. Pollut. 110, 195-205. 
40. Tam, N.F.Y., Wong, Y.S., 1996. Retention and distribution of heavy metals in mangrove soils receiving wastewater. Environ. Pollut. 94, 283-291.

41. Torres, R.J., Abessa, D.M.S., Santos, F.C., Maranho, L. a., Davanso, M.B., do Nascimento, M.R.L., Mozeto, A. a., 2009. Effects of dredging operations on sediment quality: contaminant mobilization in dredged sediments from the Port of Santos, SP, Brazil. J. Soils Sediments 9, 420432.

42. Yang, Jing; Chen, Ling; Liu, Li-zao; Shi, Wei-ling; Meng, X., 2014. Ecotoxicology and Environmental Safety Comprehensive risk assessment of heavy metals in lake sediment from public parks in Shanghai. Ecotoxicol. Environ. Saf. 102, 129-135.

43. Yongming, H., Peixuan, D., Junji, C., Posmentier, E.S., 2006. Multivariate analysis of heavy metal contamination in urban dusts of $\mathrm{Xi}^{\prime}$ ' an , Central China. Sci. Total Environ. 355, 176-186.

44. Zalmon, I.R., Macedo, I.M., Rezende, C.E., Falcão, A.P.C., Almeida, T.C., 2013. Estuarine , Coastal and Shelf Science The distribution of macrofauna on the inner continental shelf of southeastern Brazil : The major in fl uence of an estuarine system. Estuar. Coast. Shelf Sci. 130, 169-178. 